\title{
Are Lithospheres Forever?
}

\author{
O'Reilly, S. Y. ${ }^{1}$, Griffin, W. L. ${ }^{1,2}$ and Poudjom Djomani, Y. ${ }^{1}$
}

1. GEMOC National Key Centre, School of Earth Sciences, Macquarie University, Sydney, NSW, 2109, Australia

2. CSIRO Exploration and Mining, PO box 136, North Ryde, NSW, 2113, Australia

\section{The lithospheric mantle and 4-D lithosphere mapping}

The subcontinental lithospheric mantle (SCLM) carries a geochemical, thermal and chronological record of large-scale tectonic events that have shaped the Earth's crust. The SCLM is part of the continental plate, and moves with the plates over the less rigid asthenosphere. It has long been accepted that "old" (cratonic) lithosphere is relatively deep, depleted and cold; more recently it has been recognised that "young" lithosphere is relatively thin, fertile and hot.

Development of the 4-D Lithosphere Mapping methodology (O'Reilly and Griffin 1996) has provided tools for constructing realistic geological sections of the SCLM. Xenoliths and garnet and chromite xenocrysts from mantle-derived volcanics (eg basalts, lamproites, kimberlites) provide samples of the lithospheric mantle at the time of eruption. Where sufficient xenoliths and/or xenocrysts of appropriate composition are available, we can determine the paleogeotherm, the depth to the crust-mantle boundary, the detailed distribution of rock types with depth, the spatial distribution of fluid-related (metasomatic and anatectic) processes and the depth to the lithosphere-asthenosphere (LAB) boundary within the tectosphere. Volcanic episodes of different ages in one region provide this information for different time-slices corresponding to ages of the volcanism, while geophysical data (seismic, gravity, magnetic, thermal) can be used to extend the geologically-derived profiles laterally or to interpret lithospheric domains with geophysical signatures that can be matched with geologically mapped sections.

4-D lithosphere mapping shows that the depth of the LAB can range from about 250 to 150 $\mathrm{km}$ in cratonic areas, while it is seldom $>150 \mathrm{~km}$ in circumcratonic areas. Distinctive rock-type profiles (mantle stratigraphy) can be mapped, followed laterally, and correlated with surface geology (Griffin et al, this vol.). In Siberia within-craton domains with distinctive mantle stratigraphy coincide with crustal terranes mapped at the surface (Griffin et al. 1998b). Markedly different SCLM sections sampled by Ordovician kimberlites in the Sino-Korean craton suggest that the major TanLu fault penetrates the lithospheric mantle and separates two Archean terranes (Griffin et al. 1998e). These studies provide evidence that individual Archean terranes or microcontinents developed their own distinctive SCLM, which survived accretion of the terranes into cratons and plate-tectonic translation during subsequent aeons. However, later tectonothermal events, such as rifting or large-scale magmatism, are associated with major changes in SCLM thickness and stratigraphy, and especially in composition. Why is this so?

\section{Secular Variation in Lithosphere Composition}

Boyd (1989, 1997) recognised a fundamental distinction between Archean cratonic mantle, represented by xenoliths in African and Siberian kimberlites, and Phanerozoic circumcratonic mantle, represented by xenoliths in intraplate basalts and by orogenic lherzolite massifs. Archean xenoliths are not only more depleted on average, but have higher $\mathrm{Si} / \mathrm{Mg}$ (higher opx/olivine), and subcalcic harzburgites are well-represented in Archean xenolith and xenocryst suites, but essentially absent in younger ones. Analysis of $>13,000$ garnet xenocrysts from volcanic rocks worldwide shows a clear correlation of garnet composition with the tectonothermal age of the crust penetrated by the volcanic rocks (Griffin et al. 1998a,d). The xenolith and garnet data, taken together, indicate that the Archean/Proterozoic boundary represents a major change in the nature of lithosphere-forming processes. The garnet data further indicate that newly-formed SCLM has become progressively less depleted from Archean, through Proterozoic to Phanerozoic time.

In xenoliths, the $\mathrm{Cr}_{2} \mathrm{O}_{3}$ content of garnet correlates well with the $\mathrm{Al}_{2} \mathrm{O}_{3}$ content of the host rock (Griffin et al. 1998c). Xenolith suites also show good correlations between the content of $\mathrm{Al}_{2} \mathrm{O}_{3}$ and those of other major and minor elements; these correlations make it feasible to calculate the composition of a mantle section, given the median $\mathrm{Cr}_{2} \mathrm{O}_{3}$ content of garnet xenocrysts from that section (Griffin et al. 1998c; Table 1). The mean composition of SCLM beneath terrains of Archean, Proterozoic and Phanerozoic tectonothermal age, calculated in this way, show a clear 
secular evolution in all measures of depletion, such as $\mathrm{Al}, \mathrm{Ca}, \mathrm{mg \#}$, and $\mathrm{Fe} / \mathrm{Al}$ (Table 2). Pristine Proterozoic SCLM is moderately depleted, and intermediate in composition between Archean and Phanerozoic SCLM. Cenozoic SCLM, exemplified by Zabargad peridotites and by garnet peridotite xenoliths from young extensional areas of China, Siberia and Australia, is only mildly depleted relative to Primitive Mantle. SCLM beneath some Phanerozoic terrains, especially in Europe, is more depleted and may represent reworked Proterozoic SCLM (Table 2: "preferred").

\section{Significance of SCLM evolution to geophysical interpretation}

Average mineral compositions for each age group have been used to calculate average modes, densities and seismic velocities (Table 2). Archean SCLM is $2.5 \%$ less dense than the asthenosphere (approximated by PM); for the less-depleted Phanerozoic mantle the difference is $<1 \%$. Thermal expansion coefficients are identical within error for all compositions, so that these differences persist to high temperatures. At $25^{\circ} \mathrm{C}$, the $\mathrm{V}_{\mathrm{p}}$ and $\mathrm{V}_{\mathrm{s}}$ of Archean SCLM are higher than that of Phanerozoic SCLM by ca $0.5 \%$ and $1.2 \%$, respectively; the compositional differences thus account for ca $25 \%$ of the range observed by seismic tomography. Typical geotherms for cratonic and Phanerozoic areas were used to calculate the difference in $V_{p}$ and $V_{s}$ at $100 \mathrm{~km}$ depth; the Archean values are higher by $4-5 \%$, corresponding to the ranges commonly seen by seismic tomography.

\section{Lithosphere evolution and destruction}

These physical property data are important constraints on the delamination and recycling of the SCLM. Archean lithosphere is highly refractory and buoyant compared to the asthenosphere $(\approx \mathrm{PM}$; Table 2$)$; this is progressively less true of younger lithosphere. Calculation of the Tdependent density variation with depth for typical Archean, Proterozoic and Phanerozoic geotherms shows that minimum thicknesses of $>220 \mathrm{~km} \mathrm{~km}, 150 \mathrm{~km}$ and $75 \mathrm{~km}$, respectively, must be reached before the mantle section becomes neutrally buoyant, which is the minimum condition for lithosphere delamination. This effect explains the thickness and apparent longevity of existing Archean lithosphere, but suggests that deep continental roos could be constructed from material similar to Phanerozoic lithosphere.

Tectonic or magmatic events that lead to the replacement of old SCLM by younger material cause changes in the density and geotherm of the lithospheric column, with major effects at the surface. In the Kaapvaal Craton (Brown and Griffin, this volume) thermal and chemical erosion produced in a thinner, hotter and chemically recharged (metasomatised) lithosphere, and led to significant uplift of the craton. In the eastern Sino-Korean craton, the removal of $\geq 100 \mathrm{~km}$ of Archean lithosphere during the late Mesozoic was accompanied by uplift, basin formation and widespread magmatism. In this case, lithosphere replacement involved rifting, with contemporaneous upwelling of fertile asthenospheric material (Griffin et al., 1998e; Yuan 1996).

\section{Conclusions}

Correlations between mantle type and crustal age indicate that continental crust and its underlying SCLM were formed together and remain coupled for geologically long times. Destruction of Archean SCLM is difficult, but where it occurs, by thermal and chemical erosion and/or rifting, thinning and displacement, it has major thermal and tectonic consequences.

\section{References}

Boyd, F.R., 1989, Composition and distinction between oceanic and cratonic lithosphere. Earth Planet. Sci. Lett., 96, 15-26.

Boyd, F.R., 1997, Origin of peridotite xenoliths: major element considerations. In G. Ranalli et al. (eds.), High pressure and high temperature research on lithosphere and mantle materials. Univ. of Siena.

Griffin, W.L., Fisher, N.I., Friedman, J., Ryan, C.G. and O'Reilly, S.Y. 1998a. Cr-pyrope garnets in the lithospheric mantle: I. Compositional systematics and relations to tectonic setting. Jour. Petrol. (subm.)

Griffin, W.L., Kaminsky, F.V., Ryan, C.G., O’Reilly, S.Y., Natapov, L.M. and Ilupin, I.P., 1998b, The Siberian Lithosphere Traverse: Mantle terranes and the assembly of the Siberian craton. Tectonophysics (subm).

Griffin, W.L., O'Reilly, S.Y. and Ryan, C.G., 1998c, The composition and origin of subcontinental lithospheric mantle. In Y. Fei (ed.) Mantle Petrology: Field observations and high-pressure experimentation (in press). 
Griffin, W.L., O'Reilly, S.Y., Ryan, C.G., Gaul, O. and Ionov, D. 1997d. Secular variation in the composition of subcontinental lithospheric mantle. In J. Braun et al. (eds), Structure and evolution of the Australian continent, Geodynamics Vol. 26, Amer. Geophys. Union (in press).

Griffin, W.L., Zhang, A., O'Reilly, S.Y. and Ryan, C.G. 1998e, Phanerozoic evolution of the lithosphere beneath the Sino-Korean Craton. In: M. Flower et al. (eds) Mantle Dynamics and Plate Interactions in East Asia Amer. Geophys. Union, in press.

O'Reilly, S.Y. and Griffin, W.L. 1996, 4-D lithospheric mapping: a review of the methodology with examples. Tectonophysics 262, 3-18.

Yuan, X.,1996, Velocity structure of the Qinling lithosphere and mushroom cloud model. Science in China, Series D, 39, 235-244.

Table 1. Comparison of mean mantle compositions calculated from garnets, with average compositions of xenolith suites

$\begin{array}{cccccc}\text { Kaapvaal <90MA } & \text { Kaapvaal } & \text { Kaapvaal <90MA } & \text { Kaapvaal } & \text { Vitim } & \text { Vitim } \\ \text { Gnt. Lherz. } & \text { Lherz. Xens } & \text { Gnt. Harz. } & \text { Harz. Xens } & \text { Gnt. Lherz. } & \text { Lherz. Xens } \\ \text { Calc. from Gnts } & \text { Median } & \text { Calc. from Gnts } & \text { Median } & \text { Calc. from Gnts } & \text { Median }\end{array}$

$\begin{array}{lcccccc}\mathrm{SiO}_{2} & 46.0 & 46.6 & 45.7 & 45.9 & 44.5 & 44.5 \\ \mathrm{TiO}_{2} & 0.07 & 0.06 & 0.04 & 0.05 & 0.15 & 0.16 \\ \mathrm{Al}_{2} \mathrm{O}_{3} & 1.7 & 1.4 & 0.9 & 1.2 & 3.7 & 4.0 \\ \mathrm{Cr}_{2} \mathrm{O}_{3} & 0.40 & 0.35 & 0.26 & 0.27 & 0.40 & 0.37 \\ \mathrm{FeO} & 6.8 & 6.6 & 6.3 & 6.4 & 8.0 & 8.0 \\ \mathrm{MnO} & 0.12 & 0.11 & 0.11 & 0.09 & 0.13 & 0.10 \\ \mathrm{MgO} & 43.5 & 43.5 & 45.8 & 45.2 & 39.3 & 39.3 \\ \mathrm{CaO} & 1.0 & 1.0 & 0.5 & 0.5 & 3.3 & 3.2 \\ \mathrm{Na} & 0.12 & 0.10 & 0.06 & 0.09 & 0.26 & 0.32 \\ \mathrm{NiO} & 0.27 & 0.28 & 0.30 & 0.27 & 0.25 & 0.25\end{array}$

Table 2. Calculated mean compositions for Archean, Proterozoic and Phanerozoic SCLM Archean Proterozoic Proterozoic Phanerozoic Phanerozoic Prim. Mantle Gnt SCLM Gnt SCLM xens, massifs Gnt SCLM spinel perid. (McD. \&Sun)

$\begin{array}{lcccccc} & & & & & \text { (preferred) } & \\ \mathrm{SiO}_{2} & 45.7 & 44.7 & 44.6 & 44.5 & 44.4 & 45.0 \\ \mathrm{TiO}_{2} & 0.04 & 0.09 & 0.07 & 0.14 & 0.09 & 0.2 \\ \mathrm{Al}_{2} \mathrm{O}_{3} & 0.99 & 2.1 & 1.9 & 3.5 & 2.6 & 4.5 \\ \mathrm{Cr}_{2} \mathrm{O}_{3} & 0.28 & 0.42 & 0.40 & 0.40 & 0.40 & 0.38 \\ \mathrm{FeO} & 6.4 & 7.9 & 7.9 & 8.0 & 8.2 & 8.1 \\ \mathrm{MnO} & 0.11 & 0.13 & 0.12 & 0.13 & 0.13 & 0.14 \\ \mathrm{MgO} & 45.5 & 42.4 & 42.6 & 39.8 & 41.1 & 37.8 \\ \mathrm{CaO} & 0.59 & 1.9 & 1.7 & 3.1 & 2.5 & 3.6 \\ \mathrm{Na} 2 \mathrm{O} & 0.07 & 0.15 & 0.12 & 0.24 & 0.18 & 0.36 \\ \mathrm{NiO} & 0.30 & 0.29 & 0.26 & 0.26 & 0.27 & 0.25 \\ \mathrm{mg} \# & 92.7 & 90.6 & 90.6 & 89.9 & 89.9 & 89.3 \\ \mathrm{Mg} / \mathrm{Si} & 1.49 & 1.42 & 1.42 & 1.33 & 1.38 & 1.25 \\ \mathrm{Ca} / \mathrm{Al} & 0.55 & 0.80 & 0.80 & 0.82 & 0.85 & 0.73 \\ \mathrm{Cr} / \mathrm{Cr}+\mathrm{Al} & 0.43 & 0.30 & 0.30 & 0.17 & 0.18 & 0.05 \\ \mathrm{Fe} / \mathrm{Al} & 4.66 & 2.64 & 2.64 & 1.66 & 2.23 & 1.30 \\ \mathrm{ol} / \mathrm{opx} / \mathrm{cp} / \mathrm{gnt} & 69 / 25 / 2 / 4 & 70 / 15 / 7 / 8 & 70 / 17 / 6 / 7 & 60 / 17 / 11 / 12 & 66 / 17 / 9 / 8 & 57 / 13 / 12 / 18 \\ \mathrm{density}, \mathrm{g} / \mathrm{cc} & 3.31 & 3.34 & 3.34 & 3.37 & 3.36 & 3.39 \\ \mathrm{Vp}\left(\mathrm{km} / \mathrm{s}, 25^{\circ}\right) & 8.34 & 8.32 & 8.32 & 8.30 & 8.30 & 8.33 \\ \mathrm{Vp}(\mathrm{km} / \mathrm{s}, 100 \mathrm{~km}) & 8.18 & 8.05 & 8.05 & 7.85 & 7.85 & - \\ \mathrm{Vs}\left(\mathrm{km} / \mathrm{s}, 25^{\circ}\right) & 4.88 & 4.84 & 4.84 & 4.82 & 4.82 & 4.81 \\ \mathrm{Vs}(\mathrm{km} / \mathrm{s}, 100 \mathrm{~km}) & 4.71 & 4.60 & 4.60 & 4.48 & 4.48 & -\end{array}$

